\title{
Self-Directed Professional Development: EFL Teachers' Understanding
}

\author{
Surendra Prasad Bhatt \\ Kathmandu University School of Education / Charles Darwin Academy Kathmandu, Nepal \\ surendra@kusoed.edu.np
}

DOI: http://doi.org/ 10.36892/ijlls.v3i4.737

$\begin{array}{ll}\begin{array}{l}\text { Received: } \\ \text { 26/10/2021 }\end{array} & \text { Abstract } \\ \text { Accepted: } & \text { the practice of self-directed professional development strategies within the theoretical } \\ 28 / 11 / 2021 & \text { framework of adult learning theory. Based on the telephone interviews with five } \\ & \text { English teachers teaching English at the secondary level of Dadeldhura district (one } \\ & \text { of the districts of Nepal), this study explored the experience of practicing self-directed } \\ \text { Keywords: } & \text { learning strategies. The study reveals that teacher teaching at the secondary level } \\ \text { Professional } & \text { faces challenges like large classes, less effective teacher training, improper use of } \\ \text { Development, } & \text { CAS, and lack of teaching material in the teaching profession. To tackle these } \\ \text { Challenges, } & \text { challenges, they adopt different strategies themselves. This study showed that methods } \\ \text { Collaboration } & \begin{array}{l}\text { like reading printed materials, Internet and ICT tools, action research, reflection, and } \\ \text { collaboration among teachers are standard for their professional development. These }\end{array} \\ & \begin{array}{l}\text { strategies are very often and accessible for their professional development. Despite } \\ \text { being in remote areas of Nepal, secondary-level English teachers are self-motivated } \\ \text { to adopt different strategies for their professional development. }\end{array}\end{array}$

\section{INTRODUCTION}

Traditionally, teaching has been regarded as the transmission of knowledge from one head to another. Instead, the teaching function conveys information and motivates students, raises students' self-confidence, develops self-confidence, motivates, and creates a positive learning context (Muijs et al., 2005). In this context, teachers' professional development is not limited to developing the delivery skill in class. It is instead incorporated to prepare learners to learn also.

Today's teachers are highly educated, continually improve skills, and acquire new ones by engaging in lifelong learning. They are involved continuously in their professional growth along with their job. At the same time, increasing expectations from teacher educators by government institutions compel society to work rigorously (Thakur, 2012), which added the challenges in many ways like methodology, content, skills, and behaviors. To cope with these challenges, teachers should have a sense of motivation for continuous and career-long learning, which accelerates sustainable, intellectual, and profession-oriented maturity. To keep the profession up to date with change, teachers renew and review their skills, knowledge, attitude, and behaviors. They involve in several learning activities such as experiential learning, self-directed learning, collaborative learning, reflective practices, and virtual learning, which help them gain professional development.

\section{LITERATURE REVIEW}

\subsection{Adult Learning Theory}

Edward L.Thorndike propounded the Adult Learning Theory with the publication of his Adult Learning in 1928. Later, Thorndike, Bregman, Tilton, and Woodyard's Adult Learning (1928) contributed this theory to make it more famous. The proper name 'Adult learning theory' was given after founding adult education as a professional practice field. This theory assumes adults are 
motivated to learn as they experience needs and interests. The learning satisfies and makes it lifelong. Experience is the richest source for adults' knowledge, they have a deep need to be selfdirecting, and individual differences among people increase with age (Lindeman,1926).

I took a key component, 'Self-directed learning' from this theory for my study with the assumptions like individuals who take the initiative in learning learn more things and learn better. And self-directed learning is more in tune with our natural processes of psychological development. Many of the new products in education put a heavy responsibility on the learners to take a good deal of initiative in their learning.

\subsection{Self-directed Professional Development}

Self-directed professional development is professional learning that self-drives develop professionally with the help of self-motivation, initiation, and strong willpower (Zepeda, 2013). Teachers take the initiation for their professional development, which is more effective than other guided. Self-directed professional development enhances the sense of self-reflection and selfevaluation that gives room for correction. It enhances teacher self-reflection whereby teachers have control over their professional experiences and are motivated by tasks or problems that they find meaningful.

Choice-directed learning is self-directed where teachers have choice and interest in professional development strategies. Guglielmino (2008) opines that self-directed learning occurs in wide situations, from a teacher-directed classroom to self-planned and self-conducted learning projects developed in response to personal or workplace interests or needs and conducted independently or collaboratively. In this vein, self-directed professional development includes the collaboration of export to diagnose the condition of individual teachers, which comes from their reflection. Self-directed professional development leads teachers to identify areas for professional improvement and then guide their development in particular growth areas (Husby, 2005).

It is an ancient but relevant concept about self-directed professional development by the teacher for the teachers and of the teachers (Pierce \& Hunsaker, 1996). In regard, self-directed professional development is in learner control where their own decision guides their learning. Since they have intrinsically initiated such development activities, teachers get involved in them wholeheartedly, recognizing the necessity of continuous learning and reflective practice.

Similarly, teachers must have a solid character to follow self-directed professional development. According to Djatmiko (2011), three factors: independence to choose goals, support in the form of human and nonhuman resources to achieve goals, and personal ability required to achieve goals must be present to control the self-direct professional development. Most importantly, motivation towards the profession is the prerequisite for self-directed professional development. Intrinsic motivation encourages individuals to be more concerned and dynamic, which helps to be reflective, attentive, and updated. Self-direction is the current need to bring practical and proper changes in teaching and learning. The self-directed learning professional development approach enhances the quality of education and has a tremendous impact on improvement (Soebari \& Aldridge, 2015). The well-planned and continual self-directed professional development yields more effective professional learning than one-shot workshops and 
conferences. Thus, self-directed professional development is more relevant for professional improvement and quality education based on the individual's needs, desires, and decisions.

Self-directed learning professional development has several activities, strategies, and techniques. Action research is one of the activities used mainly by the teacher (Richards \& Farrel, 2005). Similarly, peer coaching, consulting, and class observation are also commonly used in selfdirected professional development. Professional reading and daily reflection writing are other activities and discussions with colleagues for self-directed professional development activities. Further, activities include establishing a teacher research group, exploring internet resources, and writing research reports (Visser et al., 2014). Teachers can visit the library, bookstore and also can participate in curriculum or textbook writing. Teachers can host different conferences, seminars, and training which benefits more teachers. Last but not least, preparing a teaching portfolio (Kerr, 1990) is another activity for self-directed professional development.

In this way, there are several ways that teachers can develop their professionalism in their self-initiation. A little knowledge is dangerous; teachers should have some skills before adopting some strategies for their professional development. According to Blumbers \& Michael (2009), self-study is possible when an expert acquires specific skills, recognizes the need for new knowledge, sets learning goals, explains appropriate learning questions, explores relevant knowledge, and explores a deeper understanding of the opposite. one is educated. Different skills professionals adopt different strategies for self-directed professional development.

When teachers can manage self-directed professional development, they enjoy the profession they have multiple benefits. It has a direct connection with personal, family, and social relations. The anxiety level of the teachers will decrease and will achieve a high level of motivation. Most importantly, self-directed professional development focuses on teaching practices because it improves the quality of teaching practices and positively impacts student learning and other dimensions of professional development (Lopes \& Cunha, 2017). Torres et al. (2009) argue that self-directed learning is the most critical skill for long and short educational achievement in both teaching and learning.

\subsection{Teacher Professional Development in Nepal}

Teacher professional development in the context of Nepal is highly dependent upon teacher training. Training is taken as a dominant professional development strategy in Nepal with its different modules. Mainly, pre-service and in-service are the training module given to the teachers. Pre-service training is given to the teachers before they enter the profession from colleges, universities and rarely from institutions in the form of different coursed. These courses are designed to develop multidisciplinary awareness and apply it to their real context (Mann, 2005). These courses further aim to equip specific knowledge and skills and develop attitudes before entering the profession. Education Faculty in different universities are examples of pre-service training in different levels I.Ed., B.Ed., and M.Ed. Likewise, in-service training is provided to the teacher right after they enroll in the profession. Nepal Centre for Education Development (NCED) is responsible for delivering the in-service teacher training for lower secondary and secondary are given in three modules; first module of 330 hours, second of 660 hours, and final of 330 hours within ten months(NCED). 
Apart from teacher training, as Gnawali (2016) stated that the association members learn and become resources themselves; there are several associations for teacher professional development. Conferences, seminars, and workshops are other strategies for English language teacher professional development in Nepal. Significantly, the Nepal Language English Teachers' Association (NELTA) is a pioneer organization, which organizes different seminars, conferences, and workshops with the collaboration of the British Council, the American Embassy, and other INGOs.

Likewise, the School of Education or Faculty of Education from different universities conducts workshops and seminars from teachers. Similarly, school organizations need training, and schools and teacher associations are part of teacher professional development.

Joshi et al.'s (2018) study on Nepalese EFL teachers' experience of professional development strategies reported that the EFL teachers benefited primarily from their own teaching experiences, self-monitoring workshops, and peer support. Similarly, Gnawali (2008), in his study what teacher development is and who is responsible for teacher professional development, resulted in teacher development as an ongoing process through which teachers keep growing with their voluntary effort (Head \& Taylor, 1997). Djatmiko's (2011) study on the professional development of vocational teachers led to the introduction of vocational teachers in the development of selfdirected professions. Vocational teachers can plan, do, check, and act their activity needs to enrich competencies, knowledge skills, and attitudes. These previous studies proved that self-directed professional development activities are widely used and influential among teachers.

Although these studies talked about teachers' strategies, importance, and role in teacher professional development, the actual practice, and experience of adopting self-directed professional development in Nepal are not well explored. Still, research is needed to study English language teachers' experiences and practices on self-directed professional development.

\subsection{Research Questions}

With the scenario explained in the above situation, this study aimed to explore the perceptions and the experiences of secondary level English teachers on self-directed professional development and tried to explore some of the self-initiated strategies they heavily rely on for professional development. Based on this purpose, I developed a study to answer the research question:

How do English teachers explore the experiences of adopting self-directed professional development strategies?

\section{METHODOLOGY}

\subsection{Research Design}

This study explores the perception and experiences of the English teachers teaching in secondary, primarily in under-resourced situations: remote areas. This study is qualitative which explores secondary level English teachers' experiences on adopting self-directed professional development. This study draws meaning from the participants' experiences and practice of different self-directed professional development strategies in their professional life connecting adult learning theory.

This study was conducted in Dadeldhura, a remote district of Nepal. As Dadeldhura is a remote district, there are fewer seminars, conferences, and training than the urban or developed areas for professional development. In this situation, teachers can't get much support from others. Since 
teachers do not get many opportunities from institutions, training centers, and government agencies, they generate and adopt different strategies for their professional development. In this condition, exploring their practice and experience adopting their self-directed and self-initiated strategies is more significant.

\subsection{Participants of the Study}

For this study, I have chosen four English teachers teaching English at the secondary level purposively. They have more than five years of teaching experience. The rationale of selecting four teachers with more than five years of teaching experience assumes they must have challenges as they are in a remote area and have some experience coping with these problems. The experienced story provides active, multi-voice, and accessible data on sensitive issues and topics challenging to grasp through questioning (Aarikka-Stenroos, 2010). So their stories are essential for exploring behavioral knowledge that helps organize and transfer practical expertise on a broader scope. The detail of my participants, along with their expertise and educational background, are presented in the following table:

Table 1 detail participants in terms of gender, experience, and qualification

Participant Teachers Teaching experience Qualification

\begin{tabular}{lll}
\hline Participant one & 10 & Master's in Education (English) \\
Participant two & 8 & Master's in Education (English) \\
Participant three & 5 & Master's in Education (English) \\
Participant four & 12 & Master's in Education (English) \\
\hline
\end{tabular}

As this study is qualitative, three-round telephone interviews from four teachers were administrated. It was challenging to meet participants physically because the world was facing the COVID-19 Pandemic. The government restricted people from moving around, and life was in danger. So, I decided to interview them via telephone. I used open-ended questions to collect the data based on the purpose and research question.

I recorded all the sharing recordings with the prior consent of the participants. Data were transcribed and analyzed from recordings to identify significant opinions, attitudes, experiences, and comments about the practice and understanding of adopting different self-directed professional development strategies. After the data transcription, other codes are given, and finally, different themes are made from these codes. Based on the same themes, findings are drawn.

\section{RESULTS AND DISCUSSIONS}

The result and discussions are based on the gathered data from the participant's experiences and the notion of self-directed learning theory as an essential component of adult learning theory. Following this, I drew the themes; Challenges in the teaching profession and self-directed strategies for professional development and sub-themes like dependency in printed reading materials, digital tools and Internet, reflection, action research, and collaboration. These themes are directly related to the self-directed learning theory. 


\subsection{Challenges in the Teaching Profession}

When interviewed, most English language teachers teaching at the secondary level reported that they are well aware of professional development and its crucial role in their personal lives. Their responses regarding the reason for choosing this profession are their passion and respect from society and students. As the teaching profession is their passion, the hunger to sharpen their profession is seen among the teachers of Dadeldhura. To polish their profession means they adopt different strategies and activities themselves despite being in remote areas. Talking with the participants, they explored teaching in remote regions brings challenges and obstacles.

Regarding the challenges, my second participant's view is common to all. Their shared experiences are class size, lack of proper training, improper use of continuous assessment systems in lower classes. Participants mainly focused on the problem of large classes. Quality teaching is usually a challenge in a large class (Shamim \& Kuchah, 2016). Since the large type is equipped with different learning abilities and nature, it is challenging to address. Regarding the large class, one of my participants said,

'If I have to say in point my problems are: classes with a high number of students, students' different learning attitude. They don't want to learn and do not obey these days classroom management and diverse learning attitude of the learner. I think implementing CAS in lower secondary is the main cause of the low background of the student. We upgrade them but don't have formal learning".

This view is more or less familiar to all the participant's perspectives. The common challenges they face are like large class and mixed ability of the learners. These problems are common in Dadeldhura (Nepal) and China, Japan, Thailand, Senegal, Mongolia, Cambodia, and Laos (Hasanah \& Utami, 2019). Analyzing this, large class is the common problem for non-English speaking countries.

Similarly, participants reported the improper utilization of the Continuous Assessment System (CAS) in lower classes added the burden in the upper class. CAS is the formative type of student assessment carried out during teaching-learning activities in the classroom. In Nepal, it is implemented up to class eight. Teachers in lower grades do not use CAS evaluation criteria and give scores to their students without any objective assessment (Dhakal, 2020). They upgrade students without their progress that add the burdens of secondary level teachers. My second participant said,

"I am astonished when I talk to my students and their performance. They even have basic knowledge and how they reached this level. Teachers are teaching in lower grades unaware of the essence of CAS... They just give ticks to upgrade."

Although CAS is the assessment of the individual students based on their regularity, participation, performance, and so on, the practice has not followed the pattern by using various formal and non-formal evaluation tools. Current practice is they tick the checklist at the end of the session and upgrade the students. This added a burden to the teachers. 
Adding more, my participant said they face a challenge in ICT use in class. They are facing is a lack of ICT skills, need-based training, and teaching materials. ICT skill in this era is an integral part of professional development (Yu, 2018). Training given to the teacher must develop ICT skills, which is lacking among the teachers in Dadeldhura. ICT skill is one of the challenges of teacher teaching in the EFL context (Charalambos \& Glass, 2007). This challenge is common in Dadeldhura as well, which is proved by the experience of my first participant as:

"I have got little training in resource center in my ten years career. Most of the training was the same, which is beyond my need and helplessness. Similarly, they provide us with teaching materials and also monthly meetings and counseling but are limited. We have to think ourselves' how to tackle with our everyday problems."

The initiation of ICT in school education is progressing through different plans. Information and Communication Technology in Education Master Plan (2013-2017) and School Sector Development Plan (2016-2023) have increased access to computers, integrating and focusing on using ICT in t schools. Expanding the use of ICT in education added challenges to the teachers. The support from an institution is insufficient, and training given to them from NCED is not need-based rather a culture only. Teacher Training is just for the sake of completing, not addressing the need of the teachers. This practice portrait that the institution and government agencies are less effective in dealing with the practical necessity of the teachers. Teachers themselves are responsible for tackling the problem they face in their profession.

\subsection{Self-Directed Strategies for Professional Development}

In the second part on how they tackled the challenges and maintained the professional development, they reported that most ideas and strategies are self-regulated and initiated. Teachers in Dadeldhura are active and conscious about professional development. Despite having many challenges and less support from school and training, they search for innovative strategies for their professional development. They are self-motivated and self-directed for tackling the challenges they face in their profession. As Demir (2017) stated, self-motivation and self-initiation can support professional development; teachers of this area are self-directed and motivated. To maintain professional development and tackle everyday challenges, they mainly rely on reading printed material, surfing the Internet, and collaborating with co-workers.

\subsection{Dependency in Printed Reading Materials}

Teachers teaching in Dadeldhura heavily rely on reading materials like newspapers, articles, and monthly magazines. Reading materials helps remove obstacles in everyday teaching and learning (Bozkus \& Bayrak, 2019). Though there aren't sufficient reading materials epically in English language teaching, they take the maximum benefit. The most commonly used reading material for teachers of this area is a monthly magazine "Sikshaka" (Teacher). Sikshya is a monthly magazine published, including news and success stories in education. It brings the success stories of teachers, policies, and talk on education, new methodologies, and many more for the teacher. Regarding the use of Sikshaka, a monthly magazine, my fourth participant said, "I read Sikshya every month. It helped me in managing the noisy class. Once I read a story on an Indian teacher 
published in one of the volumes of 2074, it helped me to manage noisy class". Similarly, regarding the benefit and use of the same magazine, my second participant said

"I usually read about the issues and challenges in teaching from different parts of the country and compare with my profession, which helped me bring change. Ummmm, last month, I read about child psychology; it helped me identify students' different learning attitudes. ..."

Readers teachers are more likely to be professional than non-readers. It helps in reducing teachingrelated burdens. In the context of the Dadeldhura, daily newspapers and other journals is common reading material for their professional development. There are several journals and periodic publications preferred by the teachers. Among them, The Journal of NELTA is a common choice for English language teachers in Nepal. My fourth participant said:

"When I was in Kathmandu during my masters, I used to go to NELTA head office and read journals and also used to bring at home for reading. But here in Dadeldhura, we get one in a year. However, we get one but also much helpful, which helps a lot. It helps me engage my students in creative work and also helps in making them autonomous on their learning.'

From the responses above, printed reading materials helped them understand classroom management and psychology and develop students' creativity and autonomy. Reading empirical results makes one aware of possible challenges and solutions in methodology, content, techniques, and classroom activities (Dreyer, 2015).

\subsection{Digital Tools and Internet}

For the teachers of Dadeldhura, the Internet and digital devices are sources to acquiring knowledge and learning skills. Using information communication technology in professional development helps in material designing, classroom management, content collection, and learning classroom etiquettes (Padurean \& Margan, 2009). Participants reported the maximum use of digital tools. Although we found a lack of sufficient training on ICT tools, teachers use these for their professional development. The same notion is seen here with my participants: they use the Internet and other ICT tools to reduce their professional stress. As professional development is to keep up to date in new skills, techniques, and methodologies in profession and self-satisfaction, my participants more or less take help from the Internet and different digital devices. As my fourth participant said:

My family lives in district headquarter; there is the Internet. Every weekend, I come to the house and search on the Internet how to teach new lessons. Like, I searched YouTube to teach prepositions which I found challenging to teach in class. Similarly, while being in the village, I mean school, I listen and watch educational talks on radio and T.V.

Even if the school lacks the Internet, teachers use their holidays and leisure time to surf and earn ICT skills. ICT skill is one of the essential factors for teachers to get well-being in the profession (Duffield, 2005). Digital tools in this age are a helpful tool for professional development for all professionals. The teachers teaching in remote areas struggle for professional development where radio and T.V. work as a helping tool. My first participant was encouraged to use the Internet. He said, "I use an interactive whiteboard for teaching. It helped me show videos, stories, and many 
more while teaching vocabulary, grammar, and comprehension." Teaching content is also easy for them using ICT tools. Regarding the use of the Internet and digital devices, my third participant viewed:

We have Internet in school though it is fragile also it works. I frequently surf the Internet to learn teaching methodology, bringing new ways to teach the same thing. If I have to list what I know from the Internet is; preparing slides, language games, and tests. That reduced my stress.

Internet-based activities like using email, creating a personal webpage, Blogs, search for new investigation on methodology and techniques are some everyday professional activities for teachers as a part of their professional development (Patahuddin, 2007). Teachers use the Internet for learning new skills and bringing new interactive and exciting activities in large classes, which reduces classroom management burden and helps address students with different abilities. In this way, teachers teaching in remote areas use the Internet and digital devices as strategies for professional development.

\subsection{Reflection, Action Research, and Collaboration}

By constantly looking into their actions and experiences, teachers can professionally grow in their workplace, self-initiated and self-motivated (Gnawali 2013). Reflecting own work for changes and improvement is one of the easiest and most common practices among teachers. Teachers of Dadeldhura also have similar kinds of practice. They use reflection as a strategy to sharpen their profession. What will be better is the question of reflection. Regarding the reflection, my first participant said, "I reflect my daily activities even monthly and yearly, which helped me level my effort." Likewise, my third and fourth participants also believe in reflection as an essential strategy for professional development. He added,

"Reflection in cool mind in bed encourages me to do new things in class. What I do is I reflect my class in terms of students' involvement in classroom activities, the interest of the student in class, learning progress, and students' assignments."

Analysis and deliberation of our activities, ideas, ideologies, and skills in teaching bring positive changes in behaviors in the profession (Bartlett, 1990). The practice of reflection is very often and common among teachers for polishing professional skills.

Reflective practices from action research have become a familiar and essential strategy for self-directed professional development. The process of teachers sharing what works, using the latest research, and reflecting on their practice leads to positive gains in teachers' development (Garcés \& Granada, 2016). Talking about the responses, almost all the teachers had action research in their profession. The reaction of my third participant was

We don't have the culture of seminars and conferences. Action research is only helping too for me in many situations. I don't record all the research reports because some are oral only; I do the action without writing formally. Action research helps me in finding the problem and solving it. Once, we did group action research: we talked with a few students about their learning issues. 
Collaborative action research for betterment among teachers helps to develop professional skills. According to Martell (2014), teachers construct their knowledge while learning from and with their colleagues. Advocating action research, my second participant added,

"The action research is in the annual plan of our school, and we have to send an action research report to the education department of our rural municipality every month. So this is compulsory for us, and it is one of the liked and practice methods for improving teachinglearning in our school."

Action research (self-initiated and institutionally initiated) is regular among teachers for improving classroom activities. Mainly, action research is to deal with the individual problem of the students. Although there are few conferences, seminars, and workshops for teachers, they begin various participatory activities such as break talks, tea talks, and special lectures between teachers. Similarly, they take help from senior teachers from Kathmandu. My third participant said,

"I telephone my teachers who taught me in my master's level and discuss the problem I got in my class. Telling an example, I called my second-semester teacher for the recommendation on listening activities in class and other appropriate apps for classroom use".

The identity of the best is continually constructed and reconstructed through the collaborative exchanges of the experiences (Walkington, 2005). School-level teachers make professional relations with university lectures for the improvement of daily classroom hazards. Collaboration with university teachers is also in practice for professional development. Similarly, association with a teacher teaching non-English subjects is also common. Although issues are different in nature and language, sometimes classroom problems are the same. So, having short talks like talking in the break and talking in a tea shop is a common strategy for tackling professional issues. For example, my first participant said, "Discussion in small groups with other subject teachers for improving professional based issues in break time is common and while in casual talk with the teachers of other subject helps a lot." The second participant narrated another example of collaboration with the teacher; he said, "Once we did a group action research, we talked with few students regarding the problems they face while learning. Those students' responses helped all the teachers".

Fullan (2001) stated that a collaborative culture is in schools is powerful learning and change agent. He further opined that teachers become aware of the many approaches and ways of doing things, engage with a range of resources, and share ideas to get perfection in the profession. Professional talk helps to be aware of the many approaches and ways of doing things, engage with a range of resources, and share ideas to locate themselves in current and potential practice. Collaboration, action research, and reflection are joint strategies for self-directed professional development among the teachers of Dadeldhura.

\section{CONCLUSIONS}

This study aimed to explore the practice and experience of adopting self-directed professional development strategies following Adult learning theory. The finding above shows that teachers, while teaching in a remote area, face challenges like large classes, diverse learning attitudes of the learners, lack of teaching materials, improper use of CAS, and lack of support from 
institutions in professional development. They stated that their training was all just for the culture, not for addressing their need. Similarly, regarding the strategies to tackle these challenges, they rely on reading material, Internet and digital devices, reflection, action research, and collaboration for their professional development. These strategies are self-directed where there is minimum or no support from the institution. These strategies are to hone their teaching skills and to deal with everyday problems. They were all aware of the professional development, and they chose this profession because of their passion. Based on the findings, there are a few recommendations. First of all, English language teachers teaching Dadeldhura are thrust into professional development so, the concerned authority should manage different conferences, seminars, need-based training, and ICT skill. The awarding of prizes to those teachers who work hard in their work is needed. This study develops one sort of understanding and comprehension on self-directed strategies adopted by the teachers for their professional development. Despite the new insight from this study, numbers of limitations need to be addressed. Firstly, it was limited to four participants from remote areas of Nepal. In addition, only depending on telephone interviews may not be helpful to explore the actual situation of adopting different strategies. Nevertheless, I hope this study raises the teachers, teacher leaders, and stakeholders to adapt to different self-initiated strategies for professional development. Finally, further research can be on the effect of these strategies of selfdirected professional development in another part of the nation.

\section{REFERENCES}

Aarikka-Stenroos, L. (2010). The contribution and challenges of narrative data in interorganizational research. In Proceedings of the 26th International IMP Conference. Budapest, Hungary.

Bartlett, L. (1990). Teacher development through reflective teaching. In J. C. Richards and D. Nunan (Eds.) Second language teacher education (pp. 62-81). Cambridge University Press.

Beatty, B. R. (2000). Teachers leading their own professional growth: Self-directed reflection and collaboration and changes in perception of self and work in secondary school teachers. $\begin{array}{llll}\text { Journal of In-Service } & \text { Education, }\end{array}$ https://doi.org/10.1080/13674580000200102

Bozkus, K., \& Bayrak, C. (2019). The application of the dynamic teacher professional development through experimental action research. International Electronic Journal of Elementary Education, 11(4),

335-352. https://www.researchgate.net/publication/331974826

Charalambos, V., \& Glass, G. V. (2007). Teacher professional development and ICT: Strategies and models. Yearbook of the National Society for the Study of Education, 106(2), 87-102. https://www.researchgate.net/publication/229521826

Demir, Y. (2017). What, how and why? A multi-dimensional case analysis of the challenges facing native and non-native EFL teachers. Pasaa, 54(12), 141-176. http://ezproxy.lib.uconn.edu/login?url=https://search.ebscohost.com/login.aspx?direct=tr $\underline{\text { ue } \& \mathrm{db}=\text { eric } \& \mathrm{AN}=\mathrm{EJ} 1171211 \& \text { site }=\text { ehost-live }}$

Dhakal, R. C. (2020). Current situation and issues of continuous assessment system in mathematics education of Nepal. NUE Journal of International Educational Cooperation, 13, 31-38. 
Djatmiko, I. W. (2011). Self-directed professional development approach: An alternative to enhance vocational teachers' character [Conference paper presentation]. International Seminar on Vocational Education and Training at Saphir Hotel, Yogyakarta on July 9th, 2011. https://www.researchgate.net/publication/228843043

Dreyer, L. M. (2015). Reflective journaling: A tool for teacher professional development. Africa Education Review, 12(2), 331-344.

Duffield, J. (2005). Mentoring a teacher preparation faculty toward technology integration. Preparing teachers to teach with technology, 325-342.

Fullan, M. (2006). Leading in a culture of change. Erişim. http://www.michaelfullan.ca/resourceassets

Garcés, A. Y. C., \& Granada, L. M. (2016). The role of collaborative action research in teachers' professional development. Issues in Teachers' Professional Development, 18(1), 39-54. https://revistas.unal.edu.co/index.php/profile/article/view/49148

Gnawali, L. (2008). Teacher development through reflective practice. Journal of Education and Research, 1(1), 69-71.

Gnawali, L. (2013). English Language teacher development through professional association: The NELTA way [Unpublished doctoral thesis]. Kathmandu University.

Gnawali, L. (2016). English language teacher development through teachers association: The case of NELTA. ELT Journal, 70(2), 170- 179. https://doi.org/10.1093/elt/ccv086

Government of Nepal Ministry of Education. (2013). Information \& Communication Technology (ICT) in Education Master Plan 2013-2017. The Authors.

Government of Nepal Ministry of Education. (2016). School Sector Development Plan 2016 2023. The Authors.

Guglielmino, L. M. (2008). Why self-directed learning? International Journal of Self-directed Learning, 5(1), 1-14.

Hasanah, N., \& Utami, P. T. (2019). Emerging challenges of teaching English in non-native English-speaking countries: Teachers' view. English Language Teaching Education Journal, 2(3), 112-120.

Head, K., \& Taylor, P. (1997). Readings in teacher development. Heinemann.

Husby, V. R. (2005). Individualizing professional development: A framework for meeting school and district goals. Corwin Press.

Joshi, D. K., Gnawali, L. \& Dixon, M. (2008). Experience of professional development strategies: Context of Nepalese EFL teachers. Pakistan Journal of Education, 35(2), 53-78.

Kerr, R. (1999). Self-discipline: Using portfolios to help students develop self-awareness, manage emotions and build relationships. Pembroke Publishers.

Littman, C. B., \& Stodolsky, S. S. (1998). The professional reading of high school academic teachers. The Journal of Educational Research, 92(2), 75-84.

Lopes, J. B., \& Cunha, A. E. (2017). Self-directed professional development to improve effective teaching: Key points for a model. Teaching and technology Education, 68(2), 262-274.

Mann, S. (2005). The language teachers' development. Language Teaching, 38(2), 103- 118.

Martell, C. (2014). Teaching emerging teacher-researchers: Examining a district-based professional development course. Teaching Education, 27(1), 88-102. http://dx.doi.org/10.1080/10476210.2015.1042855 
Muijs, D., Campbell, R. Y., Kyriakidas, L., \& Robinson, W. (2005). Making the case for differentiated teacher effectiveness: An overview of research in four key areas. School Effectiveness and School Improvement, 1(1), 51-70.

Padurean, A., \& Margan, M. (2009). Foreign language teaching via ICT. Revista de Informatica Sociala, 7(12), 97-101.

Patahuddin, S. M. (2007, June). Encouraging a novice teacher to use the Internet in primary school mathematics. Paper presented at the 4th East Asia Regional Conference on mathematics Education (EARCOME 4), George Town Penang, Malaysia.

Phyllis, B \& Joel, A. M. (1992). Development of self-directed learning behaviors in a partially teacher-directed problem-based learning curriculum. Teaching and Learning in Medicine, 4(1), 3-8. http://dx.doi.org/10.1080/10401339209539526

Pierce, D., \& Hunsaker, T. W. (1996). Professional development for the teacher, of the teacher and by the teacher. Education, 11(1), 101-105.

Richards, J. C., \& Farrell, T. S. C. (2005). Professional development for language teachers: Strategies for teacher learning. Cambridge University Press.

Shamim, F., \& Kuchah, K. (2016). Teaching large classes in difficult circumstances. In The Routledge handbook of English language teaching (pp. 527-541). Routledge.

Soebari, T. S., Aldridge, J. M. (2015). Using student perceptions of the learning environment to evaluate the effectiveness of a teacher professional development programme. Learning Environments Research, 18(2), 163-178.

Thakur, G. (2012). Self-directed professional development through online resources [MIT-D.T. University conference paper]. https://www.researchgate.net/publication/327108720

Torres, P. E., Whitebread, D., \& McLellan, R. (2018). The role of teacher regulatory talk in students' self-regulation development across cultures. In V. Grau \& D. Whitebread (Eds.), New Directions for Child and Adolescent Development (1-26).

Visser, R. D., Evering, L. C., \& Barrett, D. E. (2014). Twitter for teachers: The implications of twitter as a self-directed professional development tool for k-12 teachers. Journal of Research on Technology in Education, 46(4), 396-413.

Wallace, R. M. (2004). A framework for understanding teaching with the internet. American Educational Research Journal, 41(2), 447-488.

Yu, L. T. (2018). Native English-speaking teachers' perspectives on using videoconferencing in learning English by Taiwanese elementary-school students. JALT CALL Journal, 14(1), 61-76.

Zepeda, S. J. (2013). Professional Development: What works (2nd ed.) Routledge. https://www.slideshare.net/FathiaSamet/teachers-self-directed-development-slideshare

\section{AUTHOR'S BIO}

Surendra Prasad Bhatt is an MPhil Scholar in Kathmandu University, School of Education. Research assistant at Kathmandu University Mr. Bhatt is a visiting faculty at Rainbow International School. Currently, he is the head of the English Depart at Charles Darwin Academy (Management College). Life member of Nepal English Language Teachers' Association (NELTA), Mr. Bhatt, is an executive member of The Nepalese Society of Geolinguistics. Deputy Academic Director of ISTER Nepal, Mr. Bhatt, keeps interests in teacher wellbeing and teacher professional development. 